\title{
Use of performance indicators to assess the solid waste management of health services
}

\author{
MAYARA C. ASSIS, VANIELLE A.P. GOMES, WAGNER C. BALISTA and RODRIGO R. DE FREITAS \\ Departamento de Engenharias e Tecnologias, Centro Universitário Norte do Espírito Santo, Universidade \\ Federal do Espírito Santo, Rodovia BR 101 Norte, Km 60, 29932-540 São Mateus, ES, Brazil
}

Manuscript received on March 10, 2017; accepted for publication on July 24, 2017

\begin{abstract}
Modern society faces serious challenges, among them, the complexity of environmental problems. Thus, there are several possible sources of environmental degradation, however, the waste produced by health services have an important peculiarity due to its toxic or pathogenic characteristics, since when managed improperly provide also health risk public. The involvement of solid waste from healthcare services environmental impact integrates matters a little more complex, because in addition to environmental health, they also interfere with the healthiness of environments that generate, with the consequences of nosocomial infections, occupational health and public. Thus, the management has become an urgent need, especially when we see no use of performance indicators management in healthcare environments in the city of São Mateus, ES. For this, we used the Analytic Hierarchy Process Method to prioritize such indicators as the potential improvement in health services waste management process - WHS and thus environmental analysis was performed with the use of a template for SWOT analysis. The results showed that the performance indicator training strategies developed with employees has the greatest potential to assist in improvements in WHS (Health Services Waste) management process followed indicator knowledge of the regulations associated with procedures performed by employees and importance of biosafety regulations.
\end{abstract}

Key words: Performance indicators, SWOT Matrix, AHP, waste.

\section{INTRODUCTION}

The company faces serious challenges, among them, the complexity of environmental problems. Thus, there are several possible sources of environmental degradation, however, the waste produced by health services have an important peculiarity due to its toxic and / or pathogenic characteristics, since when managed improperly, as well as damage to the environment, provide health risk public (Rodrigues 2008).

Correspondence to: Rodrigo Randow de Freitas

E-mail: rodrigo.r.freitas@ufes.br
Waste of Health Services (WHS) were initially called Medical Waste, an explicit reference to the waste generated by the very type of establishment. It was found, however, that other types of establishments also generated waste with similar characteristics to the waste generated in hospitals. Thus, a more comprehensive and denomination currently supports the technical means, Healthcare Waste (Garcia and Zanetti-Ramos 2004) was created. Therefore, WHS is waste generated by health care providers, dental, laboratory, pharmaceutical and educational institutions and 
medical research related to both human population and veterinary (Silva and Hoppe 2005).

In Brazil, due to the precarious conditions of the waste management system, there is no precise statistics regarding the number of generators, or the amount of waste generated daily health services. According to data from the National Basic Sanitation Survey conducted by the Brazilian Institute of Geography and Statistics (IBGE) in 2000 , they were collected daily 228,413 tons of waste in the country. Overall, it is estimated that $1 \%$ of these matches the waste of health services, totaling approximately 2,300 tons per day (Garcia and Zanetti-Ramos 2004). Current data indicate that approximately 265,000 tons of WHS were collected in 2014 (ABRELPE 2014).

According to Gomes and Esteves (2012), the growing global concern over this issue has led several nations to review their legislation, these tending to become increasingly restrictive. restrictions arising mainly around the generators, which are now held accountable for the waste they produce, being forced to consign them properly. As reported by Garcia and Zanetti-Ramos (2004), large generators have greater awareness about the appropriate and necessary planning for the management of WHS. However, small generators often lack this awareness and the necessary knowledge. Often also they lack infrastructure to properly perform such management.

According to Schneider et al. (2001), the involvement of solid waste from healthcare services in the issue of environmental impact integrates matters a little more complex, because in addition to environmental health, they also interfere with the healthiness of environments that generate, with the nosocomial infections consequences, occupational and public health. Thus, it is observed that the management of WHS is presented as an urgent need, especially when we see no use of performance indicators WHS management. One can, therefore, with the aid of a decision-making method, contribute to improvements in the process, it is possible to identify vulnerabilities.

Among the decision-making methods with advanced Barbarosoglu and Pinhas (1995) and Shiau et al. (2002) highlight the Analytic Hierarchy Process (AHP), due to its simplicity, robustness and ability to assess qualitative and quantitative factors, whether tangible or intangible. From the results obtained from the AHP for the presentation of the strengths and vulnerabilities found, it uses a SWOT Matrix (Strengths, Weaknesses, Opportunities and Threats). The use of this objective tool make it easy to understand the influencing factors and present how they can affect organizational initiative, taking into account four variables (strengths, weaknesses, opportunities and threats). Based on this information, decision makers can devise new strategies.

With the above, the objective of this study was to identify performance indicators of solid waste management in the Basic Health Units (BHU) in the city of São Mateus, ES, in order to assess the situation and indicate improvements, assisting in process efficiency waste management in these establishments.

\section{MATERIALS AND METHODS}

The study was conducted in the municipality of São Mateus, located in the northern region of the Espírito Santo state: 1842 '55 "S and 39 51' 17" $\mathrm{O}$

For the centralized approach to the study of management of WHS, was used as research universe, all the basic health units (BHU) in the urban area of São Mateus / ES. They were cataloged seventeen (17) units in the urban area, located in the following neighborhoods: Aroeira, Bonsucesso, Cohab, Guriri, Pedra D’Água, Porto, Santa Tereza, Seac, Morada do Ribeirão, Vitória, Vila Nova, Santo Antonio, Aviação, ideal, Litorâneo, Sernamby and São Pedro. 
In order to achieve an appropriate position on the subject, there was a literature review, which according to Gil (2002), should be based on material already prepared, such as books and scientific articles. This technical procedure begins with the review said, and classified as follows survey by proposing direct question people (Lacerda et al. 2007).

Regarding the nature of the study, this is classified as basic, to seek to generate knowledge without practical application envisaged. As for the approach, the classification is qualitative, because the study environment is the direct source for data collection, and quantitative because it was required some statistical techniques in order to translate the knowledge generated in numbers (Lacerda et al. 2007).

This study is divided into three phases, the first consisting of the preparation of the questionnaire, followed by the application questionnaire in the Basic Health Units - UBS and the evaluation of indicators through consultation with experts.

Thus, from a previous bibliographic search was prepared questionnaire for professionals involved in health services. Since for the realization of on-site interviews, we sought attention in data collection and direct contact with the present / available professionals. This is because, according to Duarte (2004), this method requires planning, theoretical preparation and technical ability at the time of collection, transcription and data analysis. In the questionnaire addressed several issues in order to obtain information on the management of waste, awareness of respondents about the environmental issues, among other issues.

As for the interview technique used was the semi-structured type, defined as a data collection method in which the interviewer formulates basic questions on the subject, but allows, and sometimes even encourages, the interviewee can speak freely on issues that arise as the main theme of the developments (Gerhardt and Silveira 2009).
The interview guide comprised a set of questions that were collected in 29 analysis variables proposed by Ventura (2009), in which your goal, according to the author, is to capture the information about the knowledge, involvement and procedures adopted by professionals from UBS in order to investigate:

- Understanding the chain generating waste in the health establishment, from the generation stage to the final disposal of these;

- Awareness of the employee and the internal procedures for management of WHS (segregation, internal collection, packaging and internal and external storage, internal and external transport and provision for regular collection, selective collection);

- The interest and the employee's willingness to collaborate in the management phases;

- Biosecurity notions in order to minimize the risk of accidents;

- Awareness practices adopted by the institutions;

- Guidance transmitted to the employee and the procedures in accordance with the standards and relevant laws to work within a health facility, for safety and health at work and waste management;

- The main questions relevant to any of the management stages.

The 29 identified variables that formed the road map are indicated in Table I.

It is important to note that the variables mentioned above were used to investigate only the waste management group A (potentially infectious), $\mathrm{D}$ (common), and E (sharps) as waste group B (chemical) and $\mathrm{C}$ (radioactive) require detailed study of the specific procedures and relevant legislation to them (Ventura 2009). Examples of wastes belonging to the waste groups covered in this work are: 
TABLE I

Observation identified variables.

\begin{tabular}{|c|c|c|c|c|c|}
\hline \multicolumn{6}{|c|}{ VARIABLE OBSERVATION } \\
\hline 1 & Knowledge of representing the WHS & 11 & Contamination causes with WHS & 21 & $\begin{array}{l}\text { Training type that employees } \\
\text { are submitted }\end{array}$ \\
\hline 2 & $\begin{array}{l}\text { Knowledge of the management } \\
\text { responsibility of WHS }\end{array}$ & 12 & $\begin{array}{l}\text { Identification of PPE (Individual } \\
\text { protection equipment) used in } \\
\text { daily activities }\end{array}$ & 22 & $\begin{array}{l}\text { Head of interaction frequency } \\
\text { with employees }\end{array}$ \\
\hline 3 & $\begin{array}{c}\text { Knowledge about the dangers of } \\
\text { WHS }\end{array}$ & 13 & $\begin{array}{l}\text { Waste segregation practiced in } \\
\text { order to establish }\end{array}$ & 23 & $\begin{array}{c}\text { Employee satisfaction as to } \\
\text { training developed } \\
\text { official }\end{array}$ \\
\hline 4 & $\begin{array}{l}\text { Observation level on the procedures } \\
\text { performed with WHS }\end{array}$ & 14 & Internal collection type of WHS & 24 & $\begin{array}{c}\text { Knowledge about the } \\
\text { existence of HSWMP (Health } \\
\text { Services Waste Management } \\
\text { Plan) }\end{array}$ \\
\hline 5 & $\begin{array}{c}\text { Knowledge of laws / regulations } \\
\text { / plans that deal with WHS } \\
\text { management }\end{array}$ & 15 & $\begin{array}{l}\text { Knowledge about the amount of } \\
\text { generated WHS }\end{array}$ & 25 & $\begin{array}{l}\text { Involvement and employee } \\
\text { interest in discussing waste } \\
\text { management }\end{array}$ \\
\hline 6 & $\begin{array}{l}\text { Knowledge of laws / regulations } \\
\text { / plans associated with WHS } \\
\text { dangerousness }\end{array}$ & 16 & $\begin{array}{c}\text { Internal packaging location of } \\
\text { WHS }\end{array}$ & 26 & Oversight \\
\hline 7 & $\begin{array}{l}\text { Knowledge of laws / regulations / } \\
\text { plans associated with work safety in } \\
\text { handling WHS }\end{array}$ & 17 & $\begin{array}{l}\text { WHS inland transport } \\
\text { characteristics }\end{array}$ & 27 & $\begin{array}{l}\text { Judging the feasibility } \\
\text { of selective collection of } \\
\text { recyclable at the establishment }\end{array}$ \\
\hline 8 & $\begin{array}{l}\text { official judgment on the importance } \\
\text { of laws and bio-security standards }\end{array}$ & 18 & External storage site WHS & 28 & $\begin{array}{l}\text { Environmental awareness } \\
\text { level official to segregate } \\
\text { recyclable waste }\end{array}$ \\
\hline 9 & WHS handling frequency & 19 & Type of treatment given to WHS & 29 & $\begin{array}{l}\text { Procedure adopted by the } \\
\text { employee in case of doubt }\end{array}$ \\
\hline 10 & Mishandling consequences WHS & 20 & Final Form WHS disposal & & \\
\hline
\end{tabular}

Source: Adapted from Ventura (2009).

- Group A: Cultures and microorganisms' stocks, waste from genetic engineering laboratories, transfusion bags containing blood or blood products rejected by contamination or poor maintenance, carcasses, anatomical pieces, entrails, organs, tissues, body fluids.

- Group D: Remains of food, toilet paper, paper and greasy plastic diaper, pruning waste, plaster; and

- Group E: sharp materials or scaritines such as razors, needles, scalps, glass ampoules, drills, files, diamond burs, scalpel blades, lancets.

The 29 variables already mentioned were gathered in seven performance indicators also proposed by Ventura (2009):

1) Knowledge of the information contained in HSWMP;

2) Procedure performed for internally segregate the WHS;

3) WHS of the final destination notions known to the employee; 
4) Knowledge of regulations (on waste management and safety) associated with procedures performed by employees;

5) Knowledge of WHS transportation logistics practiced on site;

6) Training strategies developed with employees;

7) The importance of biosafety regulations.

The application of interviews with professionals from UBS was authorized by the Municipal Health Before the interviews, the research project was submitted to the Research Ethics Committee on Centro Universitário Norte do Espírito Santo (CEUNES) and approved under CAAE protocol.: 53479316.8.0000.5063, and compliance with all ethical standards in research for development of this study (Resolution 466/12). Before the interviews was made a questionnaire pre-test in order to verify the usefulness of the collection instrument for further application in the real public interest.

Only one attendant from each Health Unit was interviewed due to availability at the time of the visit. Also, no pharmacists were identified in the units.

After the questionnaire in UBS's to select the observation variables and raise the characteristics of the procedures performed, we used an instrument for assessing indicators. The technique used to rank the identified attributes and build an ordering of these elements was the AHP. From the results, the strengths and vulnerabilities of WHS management process through the SWOT matrix were identified.

\section{ANALYTIC HIERARCHY PROCESS (AHP)}

It is a multi-criteria analysis method which consists in taking decisions involving complexity and subjectivity (Saaty 1988). For Saaty (1990), the AHP seeks to address this complexity by decomposing the problem into a hierarchical structure, forming an inverted tree, where the first level is the goal or decision goal, through criteria, sub-criteria and alternatives in successive levels, causing the latter has a priority order.

It was developed hierarchical structure proposed by the AHP with the definition of the overall objective (level 1), the factors (level 2) and alternative (level 3). It adopted an assessment of indicators through consultation with experts. Therefore, we used the sense value of each specialist, by comparing between said factors to build the matrix of comparisons inspired by the method (Ventura 2009). The profile of experts was composed of researchers and health professionals. For this step took the Consent to Research, the Charter Explanatory Experts containing the guidelines to conduct review and Microsoft Excel $^{\circledR}$ spreadsheet in 2013 for completion of trials experts. The record reviews were done individually via email, through the spreadsheet fill. Finally, all collected results were gathered in a single table and treated in accordance with the method.

Comparisons of experts determine the relative importance between them, capturing objective and subjective measures. Such comparisons track pair is converted into numerical values in a series of square matrices, using the basic scale of Saaty, consisting of values representing the intensity of the comparative trials (Vilas Boas 2006).

The recommended range for Saaty (2000), shown in Table II, from 1 to 9 , with 1 signifying indifference importance of a criterion relative to one another, and 9 means the extreme importance of a criterion over another, with intermediate stages of importance between these levels. Moreover, disregarding the comparisons between the criteria themselves, representing 1 on the scale, only half of the comparisons must be made, because the other half is made up of reciprocal comparisons in the matrix comparisons, which are the reciprocal values already compared (Menezes 2015).

As Menezes (2015), the trial reflects the answers of two questions: which of the two elements is more important with respect to a higher 
TABLE II

Primary Scale Saaty.

\begin{tabular}{ccc}
\hline $\begin{array}{c}\text { Intensity of } \\
\text { Importance / } \\
\text { Preference }\end{array}$ & Definition & Explanation \\
\hline 1 & Equally important / better & Both factors are equally important / preferable \\
3 & Importance / moderate preference & Importance / moderate preference for one of the factors \\
5 & Importance / strong preference & Importance / strong preference for one of the factors \\
7 & Importance / strong preference & $\begin{array}{c}\text { Importance / strong preference for one of the factors } \\
\text { Importance / Preference absolutely greater by a factor }\end{array}$ \\
\hline $2,4,6$ and 8 & Importance / absolute preference & Intermediate values
\end{tabular}

Source: Adapted from Saaty (2000).

level of discretion, and to what extent, using the scale of 1-9, in Table II.

Thus, an array of trials has been built, which in turn follows the theory of Reciprocal matrix (Figure 1), where $\mathrm{n}$ is the number of elements of the array, wherein:

$$
a_{i j}>0 \rightarrow \text { positive, } a_{i j}=1 \therefore a_{j i}=1 \mathrm{e}^{a_{i j}=1 / a_{j i} \rightarrow \text { reciprocal. }}
$$

After the weights assigned by each judge, an average of the same for well was calculated to obtain the relative weights of equal comparison between indicators. To check for deviation between the comparisons, as Berzins (2009) suggests, there was the inconsistency test, which was calculated the consistency of judgments ratio (RC) obtained by equation (1):

$$
R C=\frac{I C}{I R}
$$

Where IR is the Random Index, standardized and dependent on the matrix $\mathrm{n}$ order as shown in Table III, and IC is the Consistency Index, given by:, on what it is the largest eigenvalue of the matrix of judgments. For Saaty (2001), RC should be less than or equal to 0.20 , or $20 \%$, so it can be considered acceptable.

For the test, the matrices were submitted to the calculation of the maximum eigenvalue given by Equation (2) where $\mathrm{T}$ is the sum of the columns of the matrix and $\mathrm{w}$ is the normalized eigenvector.

$\lambda \operatorname{máx}=T . w$

Therefore, it was necessary for each trial matrix calculation of the eigenvector, which can be estimated by the geometric mean, given in Equation (3), each row of the matrix (Saaty 2001), and the following normalization was performed. According to Saaty (1991), the eigenvector is the relative importance of the analysis element for the objective to be achieved. All calculations used were carried out with the help of Microsoft Excel ${ }^{\circledR} 2013$.

$w_{i}=\sqrt[n]{\prod_{j=1}^{n} a_{i j}}$

The authors have chosen to dismiss the responses of respondents who reached levels higher than $20 \%$ of inconsistency, as established by Saaty (1980), in which case the RC value of the condition is not satisfied, you must reform the trials, or discard the evaluation.

After completing the inconsistency tests, we conducted an analysis to establish the priority order of the alternatives as improving the WHS management process, so as to respond to the 
initial objective described in the first level of the hierarchical structure. The numerical information obtained about each alternative were normalized and their relative weights (importance) were also standardized.

To go up one level of the structure, the characteristic data for the indicators are formed from the average of the data of the alternatives that make up, and the relative weight adopted for each indicator was obtained by the sum of the relative weights of their respective alternatives. To reach the final hierarchy took place multiplying the quantitative data by standard amounts and added the values obtained for each alternative.

In addition to the results hierarchy of AHP were performed hierarchical cluster analysis for similarity (cluster) and multidimensional scaling nonparametric (MDS), through Primer ${ }^{\circledR}$ software to better visualize the close relationships between indicators and alternatives, considering the degree of importance given by respondents and quantitative information collected. The hierarchical clustering interconnects the samples making associations and produces a dendrogram, so that such samples to clump together. The shorter the distance between

$$
A=\left[\begin{array}{cccc}
1 & a_{12} & \ldots & a_{1 n} \\
1 / a_{21} & 1 & \ldots & a_{2 n} \\
\vdots & \vdots & \ldots & \vdots \\
1 / a_{n 1} & 1 / a_{n 2} & \ldots & 1
\end{array}\right]
$$

Figure 1 - Judgments Matrix - Gomes et al. (2016). the points, the greater the similarity between the samples (Moita Neto and Moita 1998). Thus, dendrograms were constructed for analysis of the similarity between the alternatives and indicators.

The MDS, for example, is used to facilitate interpretation of the results and showing its possible relationships, where each event is represented by a point in space and the distance between them is the similarity ratio (Steyvers 2001). For this study were built for MDS's indicators and alternatives.

\section{SWOT MATRIX}

From the results obtained from the AHP for the presentation of the strengths and vulnerabilities found, it elaborated a SWOT matrix, considered an essential tool in plans organization and defining decision-making strategies. The SWOT matrix was used in this study to promote a diagnosis of WHS management process. According to Dantas and Melo (2008), this matrix is presented as a scenario analysis and is divided into internal environment (strengths and weaknesses) and external environment (opportunities and threats).

Corroborating, Chiavenato (2003) confirms the need to conduct the analysis of internal and external factors, which should be explored, contained, expanded and improved or corrected.

\section{RESULTS}

The survey was conducted in 12 UBS because the other units could not be contacted or refused to participate / answer questionnaires. The profile of respondent's localities covered

TABLE III

Random Index.

\begin{tabular}{|c|c|c|c|c|c|c|c|c|c|c|c|c|c|}
\hline $\mathbf{n}$ & 3 & 4 & 5 & 6 & 7 & 8 & 9 & 10 & 11 & 12 & 13 & 14 & 15 \\
\hline IR & i & i̊ & $\dot{\bar{N}}$ & $\underset{+}{\vec{\perp}}$ & $\underset{\sim}{\sim}$ & $\stackrel{\overrightarrow{ \pm}}{\overrightarrow{ \pm}}$ & $\overrightarrow{\vec{u}}$ & $\vec{t}$ & $\ddot{\text { in }_{1}}$ & $\underset{\dot{\phi}}{\ddot{n}}$ & ĭ & $\vec{y}$ & $\overrightarrow{i_{0}}$ \\
\hline
\end{tabular}

Source: Saaty (1991). 
different professionals, counting, therefore, with the participation of nurses, nursing technicians, general assistant (professional cleaning) and nursing leaders. The questionnaire was applied to an employee at a UBS due to the dependency on the availability of each participant at the time of the site visit. It was not possible to interview doctors of these establishments because such professionals do not have the time and interest to participate in this work.

After the questionnaire with employees of UBS be deleted or group some variables, reducing to 13 the number of variables to be addressed at the next work step. This change was due to the fact that some activities practiced in these establishments are compatible with some variables in question, making the approach less relevant same. Thus, the observed variables in the new stage of work are shown in Table IV:

From the available literature review on the topic, the hierarchical structure proposal was developed by AHP, with the definition of the overall objective (level 1), indicators (level 2) and alternative (level 3), as shown in Figure 2.

In order to meet the priorities in relation to indicators, as the construction of the headquarters and pairwise comparisons, following the proposal of the presented method, it was sent to 13 experts to trial sheet. They were obtained and used judgments of 9 experts who answered the matrix of comparison sent by e-mail within the time specified by the authors. Thus, the inconsistency test was performed separately for each expert. However, experts of 2 trials were discarded by getting a consistency ratio greater than $20 \%$. Each expert filled eight spreadsheets, and one for the trial pairwise indicators and seven intended for trial pairwise alternatives with respect to indicators. The parity comparison of an array of alternative one interviewee can be found in Figure 3 wherein each alternative was compared pairwise with respect to an indicator. For this judgment matrix follows the applied inconsistency test (Table V).

Thus, the calculation of eigenvectors allowed to obtain the weights for each alternative to the indicator, according to Lisboa and Waisman (2003). Thus, each alternative has a relative weight found by normalization of its eigenvectors, where average of 7 answered matrices were considered. But for the weights of indicators were considered the sum of the weights of the alternatives that compose them.

Also, with regard to indicators, according to the judgment of experts, which has the highest weight is the indicator training strategies developed with the employees with $21.35 \%$, followed indicator of knowledge of regulations associated with procedures performed by employees, importance of regulations on biosafety procedures to internally segregate the WHS, with their weights: $16.91 \%$, $16.15 \%$ and $15.75 \%$.

Among the alternatives analyzed, the training they undergo the staff was considered the most weight in six of the seven indicators. Since the alternative frequency of management interaction with employees had lower weight in four of the seven indicators.

The indicator training strategies developed with the staff presents the alternative training to employees as the most important were submitted in its formation, with relative weight of $21.04 \%$ and local internal packaging of WHS with less weight $(3.95 \%)$.

The indicator knowledge of the regulations associated with procedures performed by employees also features as most important alternative training they have undergone employees, with $14.8 \%$ relative weight and frequency of management interaction with employees with lower weight (3.91\%). The indicator importance of biosafety regulations has alternative training they have undergone employees as the highest weight (13.26\%) and local external packaging of WHS with less weight 
TABLE IV

Selected observation variables.

VARIABLE OBSERVATION

1 Knowledge about the dangers of WHS

Knowledge of laws / regulations / plans that deal with WHS management

Contamination causes with residue: WHS consequence of mishandling

8

Training that employees are submitted
Type of treatment and fin
disposal data to WHS
Involvement and employee

interest in discussing waste management

12

Oversight
13
Environmental employee awareness on segregation of recyclable waste

\section{Objetivo: Identificar indicadores de desempenho do processo de gerenciamento de RSS.}

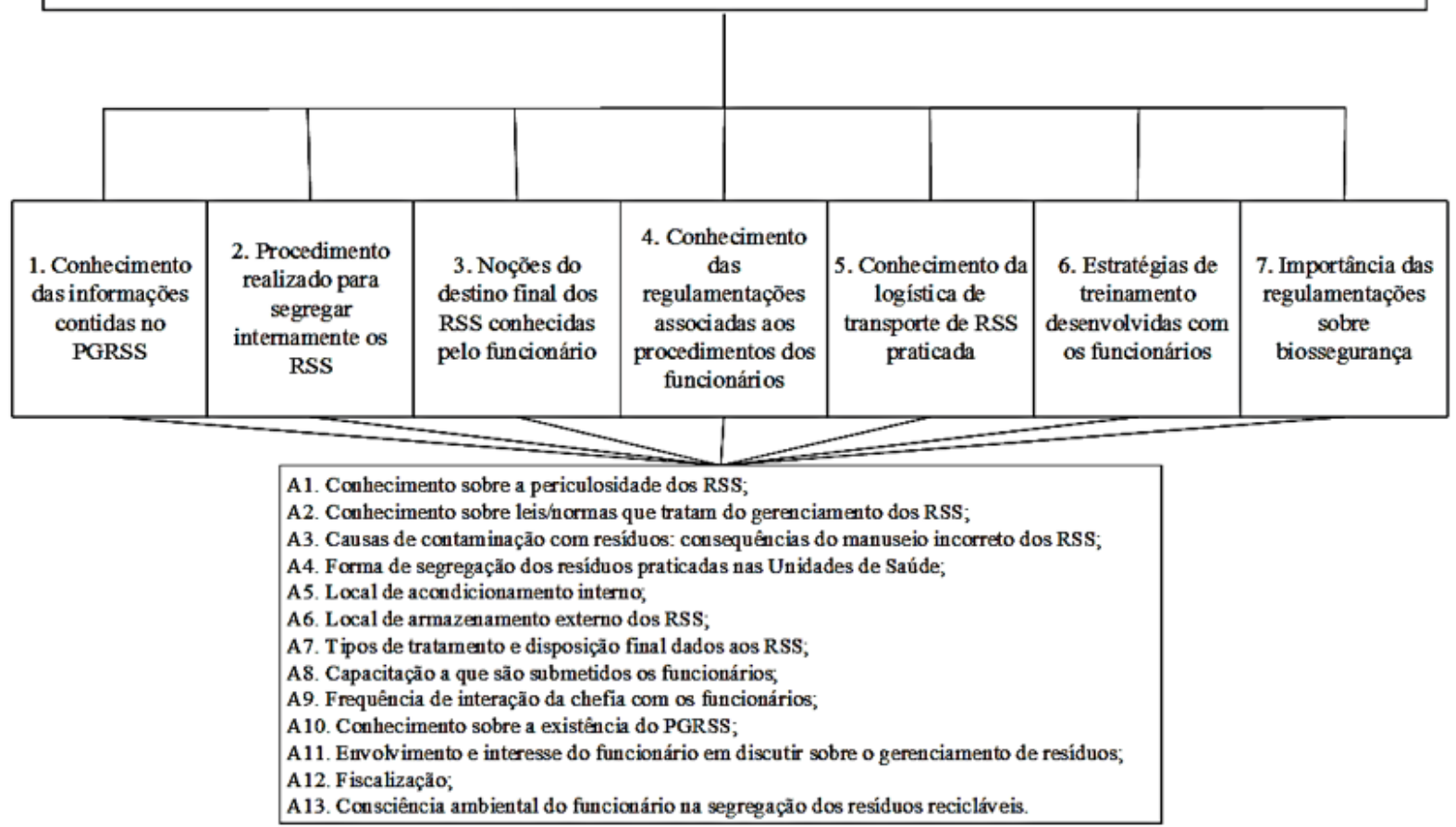

Figure 2 - Hierarchical structure decision. 


\begin{tabular}{|c|c|c|c|c|c|c|c|c|c|c|c|c|c|}
\hline $\begin{array}{l}\text { Judgments } \\
\text { matrix }\end{array}$ & $\mathbf{A}_{1}$ & $\mathbf{A}_{2}$ & $\mathbf{A}_{3}$ & $\mathbf{A}_{4}$ & $\mathbf{A}_{5}$ & $\mathbf{A}_{6}$ & $\mathbf{A}_{7}$ & $\mathbf{A}_{\mathbf{8}}$ & $\mathbf{A}_{9}$ & $A_{10}$ & $A_{11}$ & $A_{12}$ & $\mathbf{A}_{13}$ \\
\hline $\mathbf{A}_{1}$ & 1 & 3 & 1 & $1 / 5$ & 5 & 5 & $1 / 9$ & 1 & 3 & 7 & $1 / 5$ & 5 & $1 / 5$ \\
\hline $\mathbf{A}_{2}$ & $1 / 3$ & 1 & 1 & $1 / 3$ & 3 & 3 & $1 / 9$ & 1 & 3 & 5 & $1 / 7$ & 3 & $1 / 3$ \\
\hline $\mathbf{A}_{3}$ & 1 & 1 & 1 & 3 & 7 & 7 & $1 / 7$ & $1 / 3$ & 3 & 5 & $1 / 5$ & 5 & 1 \\
\hline $\mathbf{A}_{4}$ & 5 & 3 & $1 / 3$ & 1 & 3 & 3 & 1 & $1 / 3$ & 1 & 5 & $1 / 5$ & 3 & $1 / 5$ \\
\hline $\mathbf{A}_{5}$ & $1 / 5$ & $1 / 3$ & $1 / 7$ & $1 / 3$ & 1 & $1 / 3$ & $1 / 3$ & $1 / 5$ & $1 / 3$ & 1 & $1 / 7$ & 1 & $1 / 5$ \\
\hline $\mathbf{A}_{6}$ & $1 / 5$ & $1 / 3$ & $1 / 7$ & $1 / 3$ & 3 & 1 & 1 & $1 / 3$ & $1 / 3$ & 1 & $1 / 5$ & 1 & $1 / 3$ \\
\hline $\mathbf{A}_{7}$ & 9 & 9 & 7 & 1 & 3 & 1 & 1 & 1 & 3 & 3 & 1 & 5 & 1 \\
\hline $\mathbf{A}_{8}$ & 1 & 1 & 3 & 3 & 5 & 3 & 1 & 1 & 5 & 5 & 1 & 5 & 1 \\
\hline$A_{9}$ & $1 / 3$ & $1 / 3$ & $1 / 3$ & 1 & 3 & 3 & $1 / 3$ & $1 / 5$ & 1 & 1 & $1 / 5$ & 1 & $1 / 5$ \\
\hline$A_{10}$ & $1 / 7$ & $1 / 5$ & $1 / 5$ & $1 / 5$ & 1 & 1 & $1 / 3$ & $1 / 5$ & 1 & 1 & $1 / 3$ & 1 & $1 / 5$ \\
\hline$A_{11}$ & 5 & 7 & 5 & 5 & 7 & 5 & 1 & 1 & 5 & 3 & 1 & 7 & 1 \\
\hline $\mathbf{A}_{12}$ & $1 / 5$ & $1 / 3$ & $1 / 5$ & $1 / 3$ & 1 & 1 & $1 / 5$ & $1 / 5$ & 1 & 1 & $1 / 7$ & 1 & $1 / 7$ \\
\hline $\mathbf{A}_{13}$ & 5 & 3 & 1 & 5 & 5 & 3 & 1 & 1 & 5 & 5 & 1 & 7 & 1 \\
\hline
\end{tabular}

Figure 3 - Judgments matrix among alternatives with respect to an indicator.

(3.95\%). The classification of other indicators and their three priority alternatives can be seen in Table V. The relative weights observed and described, were multiplied by quantitative data collected after standard, and refer to the seven indicators included in the study, which allowed the prioritization thereof, considering the average importance that experts have for each element.

Thus, one can present the ranking of alternatives regarding the indicators, thus responding to the general objective where performance indicator training strategies developed with employees has the greatest potential to assist in improvements in WHS management process based on AHP with $21.35 \%$ of potential, followed indicator knowledge of regulations (on waste management and safety) associated with procedures performed by employees (16.91\%) and importance of biosafety regulations $(16.15 \%)$ (Table VI).

For a better view of the similarity between the indicators was performed hierarchical cluster analysis (Figure 4). You can check the dendrogram, from the information provided by the indicators Primer ${ }^{\circledR} 4$ (knowledge of regulations associated with procedures performed by employees) and 7 (importance of biosafety regulations) have a degree of similarity of $92.64 \%$ and the indicator 5 (knowledge of WHS transportation logistics practiced on site) differs as to its similarity to similarity of $83.67 \%$ of the other indicators. 
TABLE V

Inconsistency test.

\begin{tabular}{|c|c|c|c|c|c|c|c|}
\hline & Eigenvector & Normalized eigenvector (w) & Sum of columns $(\mathrm{T})$ & (T.w) & IC & IR & RC \\
\hline & 1.161 & 0.068 & 28.410 & 1.935 & & & \\
\hline & 0.895 & 0.053 & 29.533 & 1.551 & & & \\
\hline & 1.430 & 0.084 & 20.352 & 1.707 & & & \\
\hline & 1.184 & 0.069 & 20.733 & 1.440 & & & \\
\hline & 0.335 & 0.020 & 47.000 & 0.924 & & & \\
\hline & 0.479 & 0.028 & 36.333 & 1.021 & & & \\
\hline & 2.375 & 0.139 & 7.565 & 1.054 & & & \\
\hline & 2.114 & 0.124 & 7.800 & 0.967 & & & \\
\hline & 0.583 & 0.034 & 31.667 & 1.082 & & & \\
\hline & 0.392 & 0.023 & 43.000 & 0.987 & & & \\
\hline & 3.166 & 0.186 & 5.762 & 1.070 & & & \\
\hline & 0.382 & 0.022 & 45.000 & 1.007 & & & \\
\hline & 2.554 & 0.150 & 6.810 & 1.020 & & & \\
\hline TOTAL & 17.051 & 1.000 & 329.965 & 15.765 & 0.230 & 1.560 & 0.148 \\
\hline
\end{tabular}

TABLE VI

Priority Order of the alternatives according to the indicators.

\begin{tabular}{|c|c|c|c|}
\hline \multirow{3}{*}{ Training strategies developed with employees } & $1^{\mathrm{o}}$ & Training that employees are submitted & $21.04 \%$ \\
\hline & $2^{\circ}$ & $\begin{array}{c}\text { Involvement and employee interest in discussing } \\
\text { waste management }\end{array}$ & $9.42 \%$ \\
\hline & $3^{\circ}$ & Oversight & $8.76 \%$ \\
\hline \multirow{3}{*}{$\begin{array}{l}\text { Knowledge of regulations } \\
\text { (on waste management and safety) associated } \\
\text { with procedures performed by employees }\end{array}$} & $1^{\mathrm{o}}$ & Training that employees are submitted & $14.80 \%$ \\
\hline & $2^{\mathrm{o}}$ & Knowledge about the existence of HSWMP & $9.78 \%$ \\
\hline & $3^{\circ}$ & Oversight & $8.64 \%$ \\
\hline \multirow{3}{*}{ Importance of biosafety regulations } & $1^{\mathrm{o}}$ & Training that employees are submitted & $13.26 \%$ \\
\hline & $2^{\circ}$ & $\begin{array}{c}\text { Knowledge of laws / regulations dealing with WHS } \\
\text { management }\end{array}$ & $13.05 \%$ \\
\hline & $3^{\circ}$ & Oversight & $10.43 \%$ \\
\hline \multirow{3}{*}{$\begin{array}{l}\text { Procedure performed to internally segregate } \\
\text { WHS }\end{array}$} & $1^{\mathrm{o}}$ & segregation of waste form practiced in Health Units & $11.90 \%$ \\
\hline & $2^{\circ}$ & Local internal packaging & $11.68 \%$ \\
\hline & $3^{\circ}$ & Training that employees are submitted & $10.70 \%$ \\
\hline
\end{tabular}


TABLE VI (continuation)

\begin{tabular}{|c|c|c|c|}
\hline \multirow{3}{*}{$\begin{array}{l}\text { Knowledge of the information contained in } \\
\text { HSWMP }\end{array}$} & $1^{\circ}$ & Training that employees are submitted & $12.70 \%$ \\
\hline & $2^{\mathrm{o}}$ & Segregation of waste form practiced in Health Units & $10.26 \%$ \\
\hline & $3^{\circ}$ & $\begin{array}{c}\text { Knowledge of laws / regulations dealing with WHS } \\
\text { management }\end{array}$ & $9.64 \%$ \\
\hline \multirow{3}{*}{$\begin{array}{l}\text { Knowledge of WHS transportation logistics } \\
\text { practiced on site }\end{array}$} & $1^{\circ}$ & Training that employees are submitted & $14.25 \%$ \\
\hline & $2^{\mathrm{o}}$ & external storage location of the WHS & $10.48 \%$ \\
\hline & $3^{\circ}$ & $\begin{array}{c}\text { Causes contamination with residues result from } \\
\text { mishandling WHS }\end{array}$ & $9.49 \%$ \\
\hline \multirow{3}{*}{$\begin{array}{l}\text { Understanding the final destination of WHS } \\
\text { known by the employee }\end{array}$} & $1^{\circ}$ & Training that employees are submitted & $14.43 \%$ \\
\hline & $2^{\circ}$ & Type of treatment and final disposal data to WHS & $13.22 \%$ \\
\hline & $3^{\circ}$ & Oversight & $9.67 \%$ \\
\hline
\end{tabular}

MDS when prepared, it was considered the data collected and relative weights for the analysis of indicators. Thus, this analysis confirms the similarity obtained by the dendrogram. It is observed that most of the indicators are grouped on the similarity of $80 \%$ for each of them, and as already mentioned, the knowledge indicators of regulations associated with procedures performed by employees and importance of biosafety regulations are in the same group and same range of similarity (similarity $90 \%$ ).

It was also developed MDS for alternatives that make up the indicators, which made it possible to observe the similarity of $93 \%$ between alternatives 1 (knowledge of the dangerousness of the WHS), 3 (with waste contamination causes: consequence WHS from mishandling), 4 (form of waste segregation practiced in the health units) and 7 (type of treatment and final disposal data to WHS). It is important to note that the alternative 8 (training that employees are subjected) is widely dispersed the similarity of other alternative bands. This does not mean that such an alternative is a negative point for the overall goal but it got significant judgment of experts before the other alternatives, or such alternative stood out from others.

In the case of construction of the SWOT matrix in order to diagnose the scenario that includes the management of WHS, is found in Table VII the analysis, thus providing a better view of the identified potential risks and

\section{DISCUSSION}

The indicators covered in the study were used to obtain an index, and according to Jannuzzi (2004) such use is essential, because it is an operational tool to monitor, assist in planning, implementation, execution and evaluation of programs, projects and services.

Thus, considering the results obtained by applying the AHP, as the weights of the indicators, training strategies developed with staff and knowledge of the regulations associated with procedures performed by employees, were considered the most important in the opinion of experts.

According to the Ministry of Health (Brasil 1997), the training of health workers should be guided by designs that enable professionals to develop prevention, promotion, education and recovery, interacting better with the community and being able to solve more problems population frequent, reaching better results in the control of chronic diseases and their complications. However, $50 \%$ of respondents in the UBS commenter's not performing training for correct procedures with WHS. However, those who received some kind of 


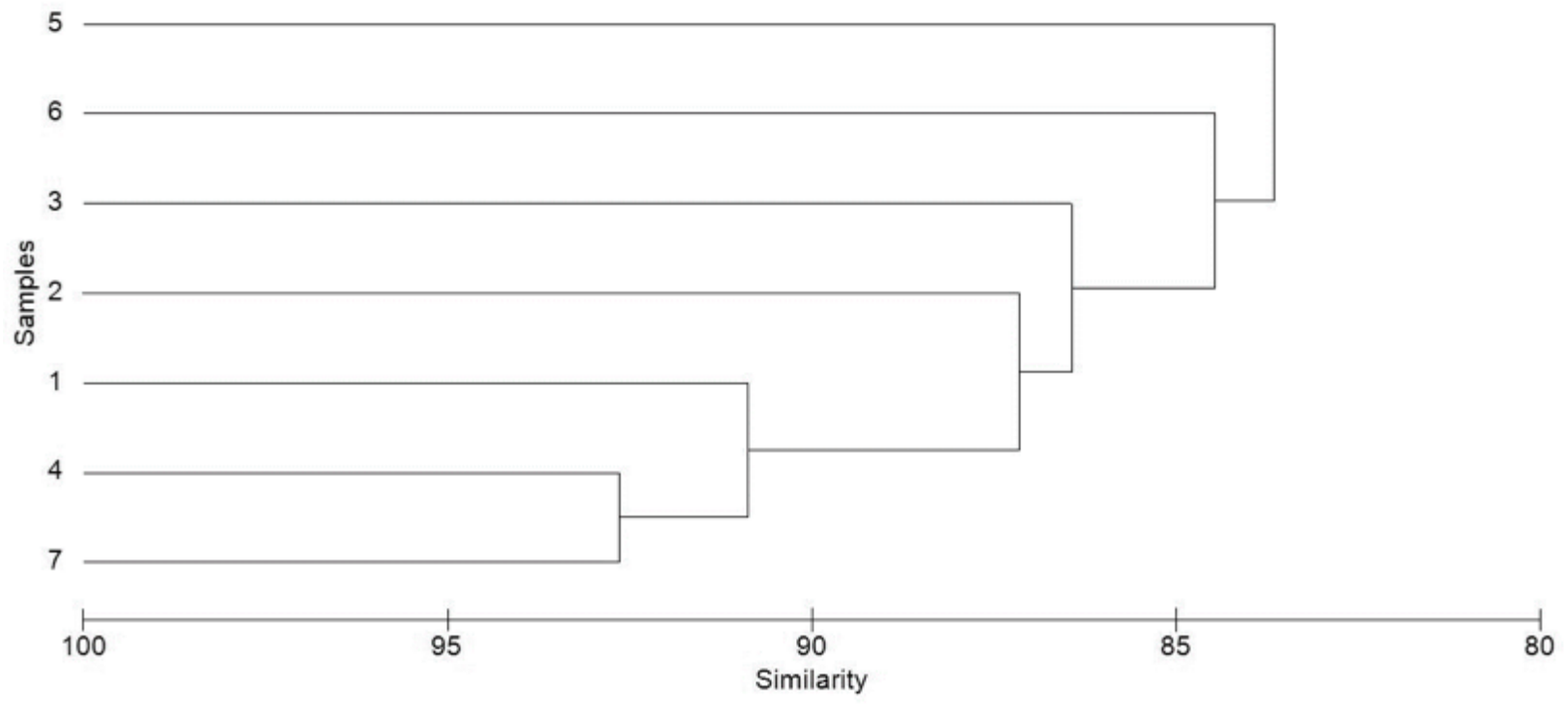

Figure 4 - Dendrogram for indicators.

TABLE VII

SWOT Matrix.

Interest of employees to participate in events related to the management of WHS;

Do not detect cases of accidents with WHS;

Awareness of the danger posed by the improper handling of WHS.

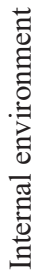

\section{Weaknesses}

Partnership with UFES for development projects in the area of public health, particularly for waste management;

Increased frequency of events regarding the management of WHS.

\section{Threats}

No need to HSWMP by employees;

Lack of PPE;

Collection of the poor WHS;

Lack of monitoring procedures by the management;

Deficient training;

Supervision loss;

Lack of space to provide service with higher quality.
Court of investments in public health; Information does not reach all hierarchical levels of the health facility. 
training, they showed dissatisfaction with the form and frequency of training.

Most respondents also showed unaware of the existence of laws / regulations / plans that address the handling and dangerousness of this type of waste. Therefore, the development of actions to address these deficiencies shown as an important tool to leverage the results of WHS management. From these actions, the other indicators and alternatives can be worked out, since many of these items are supplied through knowledge, by the employees of the Health Plan of Waste Management and other legal and regulatory bases, as for example, Decree No. 7,180 / 2014 of the City of St. Matthew which provides for packaging and disposal of waste (medical waste) and other measures; NR-32 which deals with biosecurity and health issues at work and health services; rules of the Collegiate Board Resolution (RDC) 306/04 ANVISA which deals with the technical regulation for the WHS management and CONAMA Resolution No. 358/05 which provides for treatment and final disposal of WHS and other measures.

ANVISA, in drafting its regulations, noted the different features in different municipalities, is the issue of sanitation, is the existence of suitable sites for the disposal of waste. The challenge now is, according Pierdomenico et al. (2007), to apply the Regulation in all its fullness, and this requires that all agents involved in the pursuit of this objective are fully aware of its contents.

There is, with the analysis of the similarity of the indicators, the results reinforce the similarity of the indicators with greater weight and the big difference with the indicator of lower weight.

The analysis of the results from the elaborate SWOT matrix, it is possible to visualize the potential and possible vulnerabilities found. Poor training, for example, proved to be a major impediment to the successful management of WHS and has significant representation before the claims of respondents, which, in turn, showed great interest in getting involved in awareness campaigns on correct handling WHS. Lack of PPE (Individual protection equipment) in some of the establishments studied shows how employees are exposed to the risks posed by the WHS.

Poor collection of WHS is because of irregular frequency in external collection, made by car third party. Reports indicate that in many of UBS's data collection occurs only once a week, and sometimes at intervals greater than one week. According to Brasil (2006), the internal collection of WHS should be carried out, among other factors, based on the regularity of the frequency times the external collection. In Rio de Janeiro (RJ), for example, the city determines a frequency external collection of at least twice a week for health care units (Municipality of Rio de Janeiro s.d.).

The cut in investments in health, in turn, appears as a threat to the expansion of efforts to improve the WHS management process. Managers should work effectively for the sake of obtaining more resources for the maintenance of adequate infrastructure in health facilities.

With the above, the positive and negative points WHS management process in UBS in São Mateus could be better presented. For in this way, they can be exploited potentials and adequately addressed the vulnerabilities found, making the move occurs some quantitative data of importance for the sector, noting the necessary factors to obtain a better scenario. Thus, given the importance of the study, it is suggested to expand research in order to integrate other parts of the Espírito Santo state.

\section{REFERENCES}

ABRELPE - ASSOCIAÇÃO BRASILEIRA DAS EMPRESAS DE LIMPEZA PÚBLICA E RESÍDUOS ESPECIAIS. 2014. Panorama dos Resíduos Sólidos no Brasil 2014 Disponível em: <www.abrelpe.org.br/Panorama/ panoram2014.pdf $>$. Acesso em: 04 de junho de 2016.

BARBAROSOGLU G AND PINHAS D. 1995. Capital rationing in the public sector using the analytic hierarchy process. The Engineering Economist 40(4). 
BERZINS LJ. 2009. Avaliação de Desempenho pelo AHP, através do superdecisions; Caso Inmetro. Rio de Janeiro: Faculdades Ibmec. Dissertação de Mestrado Profissionalizante apresentada ao Programa de PósGraduação em Administração das Faculdades Ibmec. (Unpublished).

BRASIL. 1997. Ministério da Saúde. Portaria nº 1.886, de 18 de dezembro de 1997, Diário Oficial da União, Brasília, p. 11-13, 22 de dez. 1997.

BRASIL. 2006. Ministério da Saúde. ANVISA Agência Nacional de Vigilância Sanitária. Manual de gerenciamento de resíduos de serviços de saúde. Disponível em: $<$ http://www.anvisa.gov.br/servicosaude/ manuais/manual_gerenciamento_residuos.pdf $>$. Acesso em 21 de jun. 2016.

CHIAVENATO I. 2003. Introdução à teoria geral da administração. $7^{\mathrm{a}}$ ed., Rio de Janeiro: Elsevier.

DANTAS NGS AND MELO RS. 2008. O método de análise SWOT como ferramenta para promover o diagnóstico turístico de um local: o caso do município de Itabaiana / PB. Caderno Virtual de Turismo 8(1): 118-130.

DUARTE R. 2004. Entrevistas em pesquisas qualitativas. Educar em Revista, Curitiba 24: 213-225.

GARCIA LP AND ZANETTI-RAMOS BG. 2004. Gerenciamento dos Resíduos de Serviços de Saúde: uma questão de biossegurança. Cad Saúde Pública. Rio de Janeiro 20(3): 744-752.

GERHARDT TE AND SILVEIRA DT. 2009. Métodos de pesquisa. Porto Alegre: Editora da UFRGS.

GIL AC. 2002. Como elaborar projetos de pesquisa. $4^{a}$ ed., São Paulo: Atlas.

GOMES LP AND ESTEVES RVR. 2012. Análise do sistema de gerenciamento dos resíduos de serviços de saúde nos municípios da bacia hidrográfica do Rio dos Sinos, Rio Grande do Sul, Brasil. Eng Sanit Ambient, Rio de Janeiro 17(4): 377-384.

GOMES VAP, JULIO TS AND FREITAS RR. 2016. IPSPA: Construção de um índice de potencialidade socioeconômico, produtivo e ambiental pesqueiro utilizando o Método AHP. Brazilian Journal of Production Engineering (BJPE) 2(1): 72-83.

JANNUZZI PM. 2004. Indicadores Sociais no Brasil: conceitos, fontes de dados e aplicações. $3^{\mathrm{a}}$ ed., Campinas: Editora Alínea.

LACERDA DP, SILVA ERP, NAVARRO LLL, OLIVEIRA NNP AND CAULLIRAUX HM. 2007. Algumas caracterizações dos métodos científicos em Engenharia de Produção: uma análise de periódicos nacionais e internacionais. In: XXVII Encontro Nacional de Engenharia de Produção, 2007, Foz do Iguaçu - PR. Anais... Rio de Janeiro: ABEPRO.

LISBOA MV AND WAISMAN J. 2003. Aplicação do Método de Análise Hierárquica - MAH para o Auxílio à Tomada de Decisão em Estudos de Alternativas de Traçado de Rodovias. XVII Congresso de Pesquisa e Ensino em Transportes, p. 982-993.

MENEZES PCF. 2015. Sistemas lógicos paraconsistentes aplicados aos modelos hierárquicos para tomadas de decisão: estudo realizado em gestão de projetos. Universidade Santa Cecília, Programa de Pós-Graduação em Engenharia Mecânica, Santos, SP. (Unpublished).

MOITA NETO JM AND MOITA GC. 1998. Uma introdução à análise exploratória de dados multivariados. Quim Nova 21: 467-469.

PIERDOMENICO F, FONSECA LC DA, PIERDOMENICO CZ, FERREIRA FRC, ROBERTA S AND BRAGA RM. 2007. RDC ANVISA No 306/04 - Aspectos jurídicos da Resolução da Diretoria Colegiada da ANVISA sobre Resíduos de Serviços de Saúde. Agência Nacional de Vigilância Sanitária.

RODRIGUES MBF. 2008. Gerenciamento de Resíduos de Serviços Odontológicos: análise comparativa entre a realidade nacional e internacional. Trabalho de Conclusão de Curso (especialização em Formação de Oficiais do Serviço de Saúde), Escola de Saúde do Exército. (Unpublished).

SAATY TL. 1980. The Analytic Hierarchy Process and Health Care Problems. New York: McGraw-Hill.

SAATY TL. 1988. The analytic hierarchy process. New York, NY: Pergamon Press.

SAATY TL. 1990. How to make a decision: The analytic hierarchy process. Eur J Oper Res, Amsterdam 48: 9-26.

SAATY TL. 1991. Método de Análise Hierárquica. McGrawHill, Makron Books, São Paulo, SP, Brasil, 367 p.

SAATY TL. 2000. Decision making for leaders. Pittsburg, USA: WS. Publications.

SAATY TL. 2001. Decision Making with Dependence and Feedback: the Analytic Network Process, 2nd edition, Pittsburgh (USA): RWS.

SCHNEIDER VE, REGO R DE CE DO, CALDART V AND ORLANDIN SM. 2001. Manual de Gerenciamento de Resíduos Sólidos de serviços de saúde. São Paulo: CLR Balieiro.

SHIAU Y-C, TSAI T-P, WANG W-C AND HUANG M-L. 2002. Use questionnaire and AHP techniques to develop subcontractor selection system. China: Chung Hua University.

SILVA CE DA AND HOPPE AE. 2005. Diagnóstico dos resíduos de serviços de saúde no interior do Rio Grande do Sul. Eng Sanit Ambient, Rio de Janeiro 10(2): 146-151.

STEYVERS M. 2001. Multidimensional scaling. Macmillan Reference Ltd.

VENTURA KS. 2009. Modelo de avaliação de gerenciamento de resíduos de serviços de saúde (WHS) com uso de indicadores de desempenho: estudo de caso: Santa Casa de São Carlos - SP. Tese (Doutorado-Programa de PósGraduação e Área de Concentração em Hidráulica e 
Saneamento). Escola de Engenharia de São Carlos da Universidade de São Paulo.

VILAS BOAS CL. 2006. Modelo Multicritérios de Apoio à Decisão Aplicado ao Uso Múltiplo de Reservatórios:
Estudo da Barragem do Ribeirão João Leite. 2006. 145 f. Dissertação (Mestrado em Economia) - Departamento de Economia da Universidade de Brasília, Brasília. (Unpublished). 